\title{
Modeling Economic Processes of Hungarian Prison Service
}

\author{
Zoltan Mezei ${ }^{1} \&$ Akos Guban ${ }^{1}$ \\ ${ }^{1}$ Budapest Business School, Budapest, Hungary \\ Correspondence: Zoltan Mezei, Budapest Business School, Budapest, Hungary.
}

Received: March 8, 2017

Accepted: March 21, 2017

Online Published: March 24, 2017

doi:10.20849/abr.v2i1.131

URL: https://doi.org/10.20849/abr.v2i1.131

\begin{abstract}
The LOST (Logistification and Standardization Techniques) project research team has already started to build unique technical-mathematical models which can be applied for economic and service processes. This research takes place at Budapest Business School. In this study we would like to reveal mainly the processes of which support the logistical analysis of production flow can be developed. We did not focus on examining the elements of processes, but our main target was the processes of the whole operational system and their relationship to each other. We explored the flowing elements in the system, such as material, data, information and human resource. We analyzed the features and the flowing features of these elements. We determined the limitations and stress of system looking for the problems caused by bottlenecks and uneconomical structure.

In the scope of this paper we present what could be a widening opportunity of the future research. By exploring the economic process of the Hungarian Prison Service (hereinafter HPS) we could have an introduction into the financial processes of Hungarian public sector. Due to the independent scope of authority of the institution, the Hungarian public sector's detailed financial management graph could be created. The purpose of our article is to identify the modules, processes and related materials and to examine their flowing and transformations as well. As this is the first milestone of a long-run project and as a consequence we form a methodology to examine the public sector organizations' economic processes on high level.
\end{abstract}

Keywords: public sector, logistic workflow, public finance, services

JEL code: $\mathrm{O} 32$

\section{Introduction}

The production or logistical systems are easily analyzable with the support of adequate modeling tools and critical locations can be found in the bottlenecks of nodes. The application of this effective technical, mathematical model could be useful for examining other process systems. Based on our research, a public finance process is likely be modeled as a supply chain process. In this research we would like to map how can a logistic, a production-logistic or a supply-chain process be modeled in technical aspect? If we can standardize this result, nothing will separate the logistic-like process from each-other and the method will be the same. A public finance transaction can be regarded as a logistic process.

In the first view, materials flow in the processes like documents, assets, invoices, etc. The flow of information is significant and not only the information flow, but the data medium, too. These data will be transformed, aggregated, stored or separated during a transaction. The process depends on nodes and time, so in this point of view it fulfills the definition of logistic process. The flow and usage of human resource are likely the same as in production process. Human resources perform transformation on data and information is similar as during a production process, because it is physically part of the entire process. The flow of energy and emission also can be found in a public finance process system (Stojkic et al., 2013).

We can see reason that the process system of our research corresponds to the definition of logistic. We have to reveal the internal features of the monitored system, after we should fit those to a logistic process, and in the end we can apply the technical-mathematical models of production logistic. In this case we can deliver successful optimizations in public finance processes with the support of target functions used in logistic. We start our examination with mapping the processes and upon the results we can observe the main nods and functions (Mezei \& Guban, 2014). 
Judgment of the Hungarian public sector organizations' operation is different in literature, but most authors agree on the fact that there are plentifully development opportunities (Palne, 2008). The requirements and recommendations correspond to objectives of public administration reforms which are known as so-called New Public Management in most places. They are the following ones (Pollit et al., 2007):

- Simple and high-level decentralized organization, divided into divisions (high-level operation);

- Transparent, contractual relationships between the stakeholders instead of hierarchical, legal conditions (innovative approach);

- Application of organizational management tools and management techniques (required quality capacity);

- Emphasizing the operation which can be divided into processes and works as a project (effectiveness);

- Measurement of results, evaluation of quality objectives' fulfillment (successfulness).

Before the detailed analyze of a budgetary management processes we need to clarify the most important related definitions. These are the followings (Guban \& Kasa, 2014):

- Fluid: is such a tangible or intangible object which may flow between two not necessarily adjacent nodes of a system or may develop or parish (expire) on a node or may undergo a quantitative and/or qualitative transformation.

- Node: is such an object of a system which is able to store data on any kind of transformation of any element (e.g. input-output transformation).

- Process: is a batch of a fluid with its interconnections which is arbitrarily and/or intentionally treated as a single unit by a business organization.

- $\quad$ Step: e.g. budgeting (elements of the budget cycle).

- Phase: e.g. commitment (during the execution of the budget).

- Module: e.g. personal benefits (level below the steps).

- $\quad$ Process: e.g. regular personal benefits (level below the modules).

Quotation from the Hungarian Prison Service's memorandum of association: "The HPS is legal personality, which owns independent budget, independent economy jurisdiction and responsibility. HPS is expected to perform tasks related to management, accounting and data service, moreover operation and investment concerning property management and also the tasks involving usage, utilization, defense of property."

According to quotation mentioned above the HPS belongs to public sector authorities which work independently. As a result of this fact it performs public financial management of each function - as highest common multiple. The public finance organizations' outstanding economic processes can be modeled and the dynamic theoretical flow-chart can be plotted by demonstrating the HPS. For this reason all the processes are not appeared on lower levels of state budget but they can be found by superior authorities.

\section{Logistics Aspect of Economic Processes}

The revenue of HPS is given by financial year's income which could be supplemented by previous years' not blocked reserves. The expenditures can have operational purposes or accumulation type. Beyond the identification of major economic processes (fluid-flow), we denominate their regulatory basis and the input/output documents as well. The budgeting cycle including the steps of management (I-V.) is found in figure 1. The I/O connections and nodes can be seen on the figure where the fluid transformation takes place.

The I/O connections and nodes can be seen on the figure where the fluid transformation takes place. 


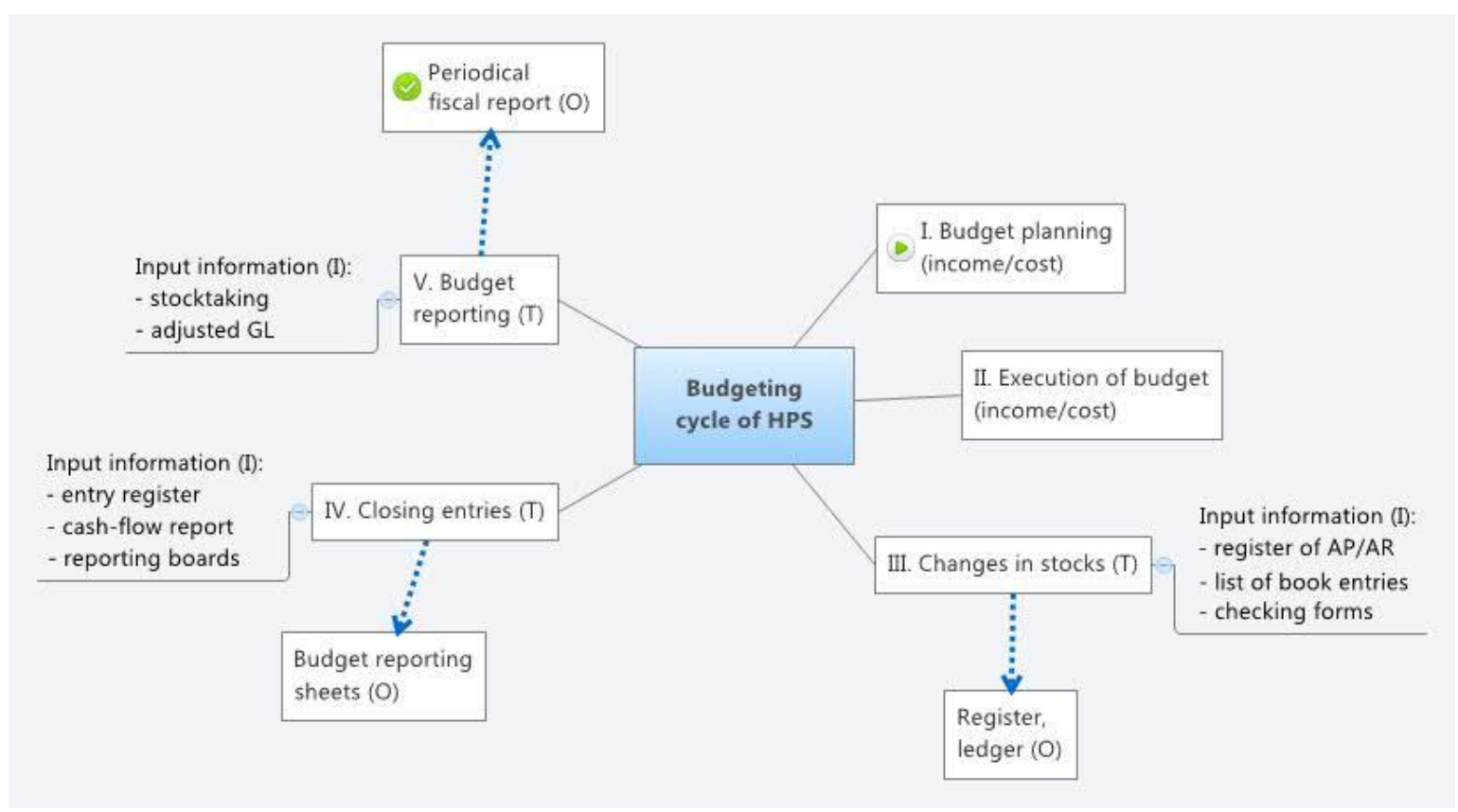

Figure 1. Steps of budgeting cycle (I: input, $\mathbf{O}$ : output, $\mathbf{T}$ : transformation)

Source: own editing

\subsection{Budget Planning}

During the budget planning the following principles should be applied (Sivak \& Vigvari, 2012):

- principle of budget based management,

- principle of programming,

- principle of completeness and detailed budget,

- principle of uniformity and transparency,

- $\quad$ principle of authenticity and aggregated cover.

Processes of budget planning step which were explored during the research $(\mathrm{I}=$ input; $\mathrm{O}=$ output $)$ are the following.

- Budget planning: Public Finance Act, Execution of State Budget, Ministry for Home Affairs' guideline (I: budget headcount limit, operational income, budget owner's claim; O: budgetary documentation, textual amendment);

- Budget planning by organizations of Hungarian Prison Services: Management Regulation, Investment Policy (I: requiring letter, planning guideline; O: budgetary documentations, textual amendment);

- Budgetary negotiation: Management Regulation, Investment Policy (I: budgetary documentation; O: record, memo, statement);

- Approval of budget: Management Regulation, Investment Policy (I: record; O: Hungarian Prison Service: Budget Act, Hungarian Prison Service organizations: approval letter)

- Drawing up of fundamental budget: Execution of State Budget (I: State Budget Act; O: documents of fundamental budget).

The I/O connections and nodes can be seen on the figure where the fluid transformation takes place. 


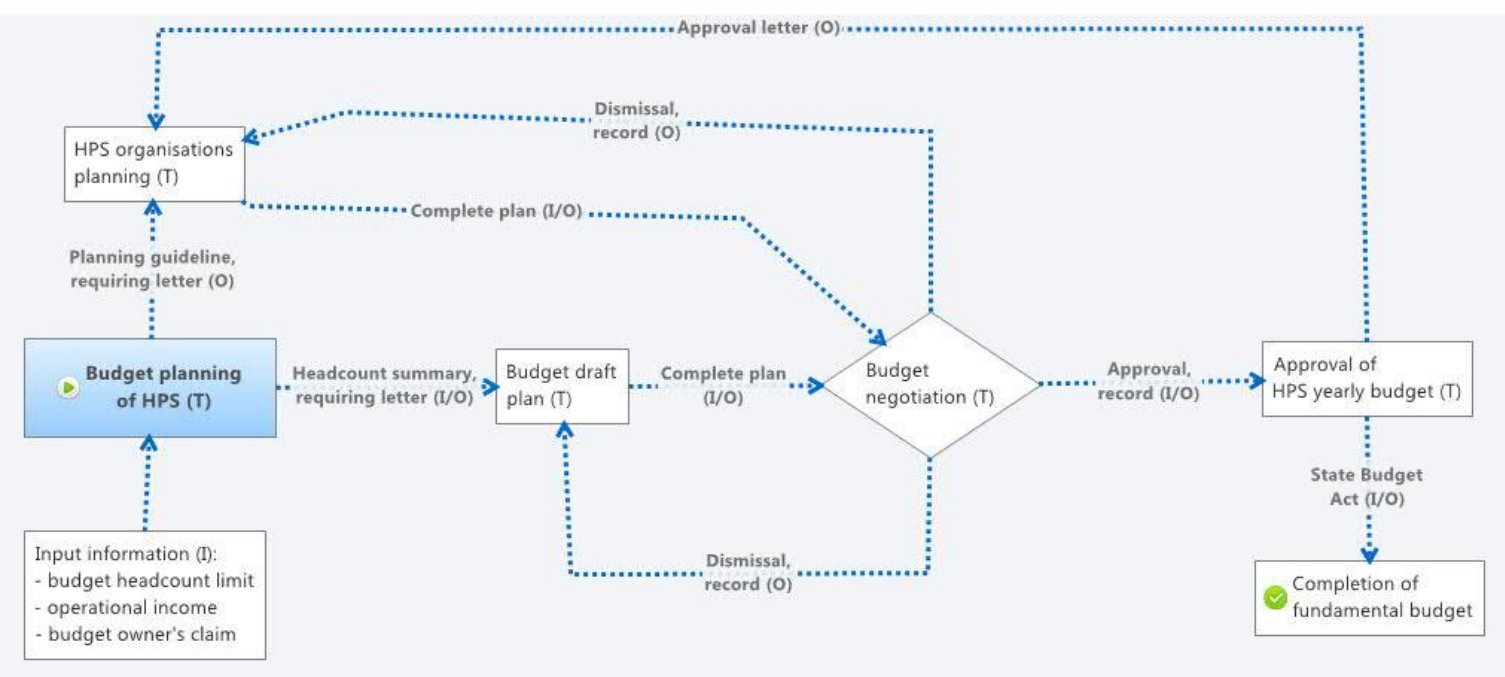

Figure 2. Budget planning dynamic flow chart (I: input, O: output, T: transformation)

Source: own editing

\subsection{Execution of the Budget}

During the execution of the budget in every case the following four phases are occurred. These phases could not be separated itemized in each case in the process described in points 1-7, because in given case inside a phase complex modules/processes can be appeared.

a) Commitment: legal certification about intention of payment obligation related to assets registered as outside funds in statement of costs. Documents (paper based or electronically stored in "Forrás SQL" - integrated management system):

- assignment document,

- confirmed order and/or contract,

- Hungarian State Treasury agreement or other document based on legislation,

- board decision or management policy.

b) Delivery: the following aspects should be verified (amount and legitimate of the expenses') and the professional performance must be proved. Documents:

- delivery note or delivery certification,

- purchase order.

c) Validation: verification that undertaking of obligation is suitable for required financial order. Documents:

- record from existence of cover and amount or

- it happened by internal policies or direction.

d) Remittance: disposition of the expenditure's fulfillment and the revenue's collection in writing

- cash voucher,

- order note of liability,

- invoice,

- certificate of invoice substitute.

\subsubsection{Personal Benefits}

Processes of personal benefits' module which were explored during the research are the following.

- Regular personal benefits: Act on Legal Status of Public Servants, Labor Code, Public service regulation, Payroll Management Regulations, Hungarian State Treasury agreement (I: record of claim announcement, O: appointment document); 
- $\quad$ Bonus and honor: Act on Legal Status of Public Servants, Labor Code, Public service regulation, Payroll Management Regulations, Hungarian State Treasury agreement (I: record of claim announcement, O: decision of chairman's meeting, notifications, organizations' lists);

- Reimbursement: Management Regulations, Public Service Regulations, Act on Legal Status of Civil Servants, Act on Legal Status of Public Servants (I: request, O: permit, study contract, travel order, accounting documents);

- Cafeteria: Public Service Regulations, Payroll Management Regulations, Hungarian State Treasury agreement (I: employee statement, O:summary table);

- Social support: Public Service Regulations, Payroll Management Regulations, Hungarian State Treasury agreement (I: request, O: Decision of the Civil Service Rules);

- Employees with contract of services: chairman direction about contract of services (I: record of claim announcement, O:legal department opinion, contract of services);

- Employer payroll contribution: Tax and contribution laws, Hungarian State Treasury agreement (I: book entry, O: tax form).

\subsubsection{Standard Material Costs}

The processes of standard material costs' module which were explored during the research are the following.

- Announcement of claim, justification of financial cover: Management regulation (I: record of claim announcement, O: requiring letter).

- Execution of necessarily procurement procedure: Public Procurement Act, Public Procurement Policy (I: requiring letter, O: Documentation of Public Procurement Regulation);

- Draft order, completing the contract: Public Procurement Act, Public Procurement Policy (I: valid proposal, O: order, contract);

- Handover of operational budget: Management Regulation (I: requiring letter, O:permission letter);

- Completion of delivery certification: Management Regulation, Asset Management Policy (I: record of fulfillment's fact, O: delivery certification);

- $\quad$ Payment of invoice: Management Regulation (I: record of verification, O: invoice, order note).

Figure 3 includes the figure of the standard material costs. The I/O connections and nodes can be seen on the figure where the fluid transformation takes place. The illustrated process' time frame is maximum 15 days (without delivery by third parties), which is determined by Organization and Operational Rules as administration duration.

The I/O connections and nodes can be seen on the figure where the fluid transformation takes place.

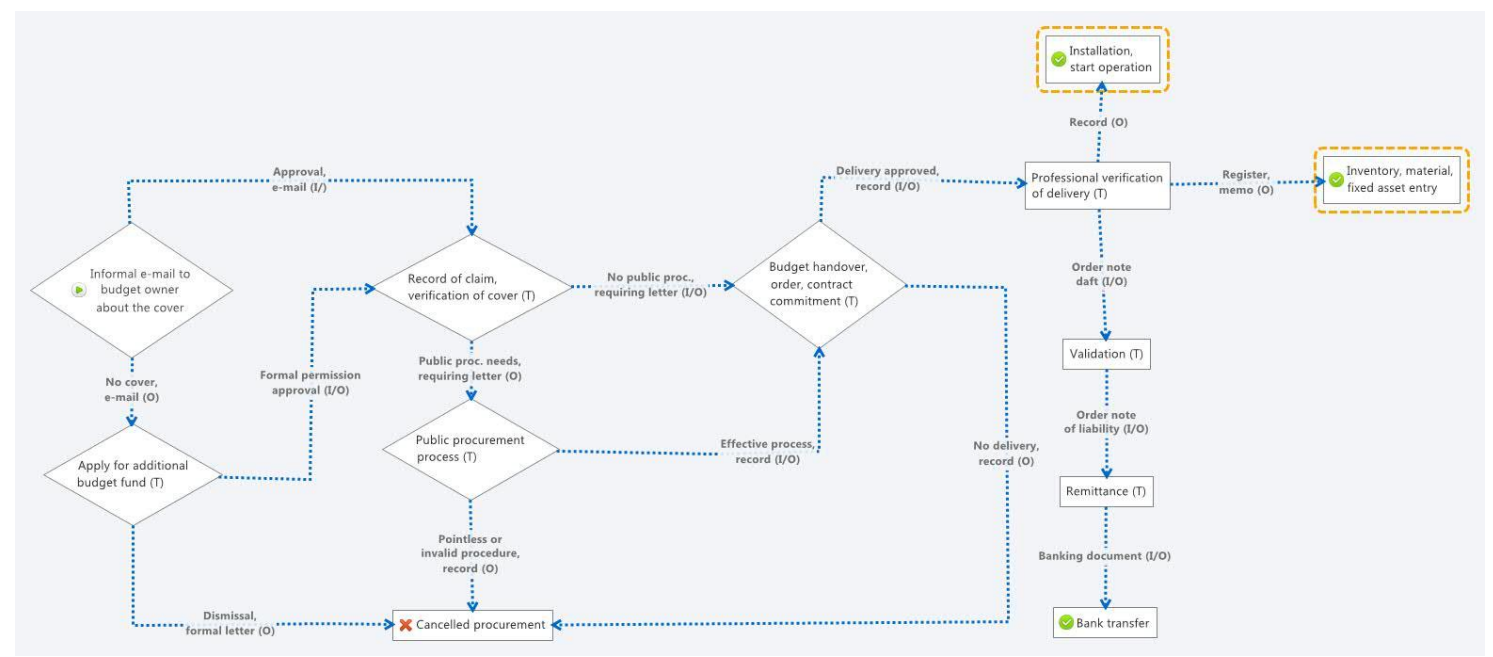

Figure 3. Process of standard material costs (I: input, O: output, T: transformation)

Source: own editing 


\subsubsection{Taxes, Fees and Payments}

Processes of the taxes, fees and payments' module which were explored during the research are the following.

- Measuring the stakeholders, calculation of payment obligation, verification of cover: Management Regulation (I: record of claim announcement, O: measuring, book entry, requiring letter);

- Execution of necessarily procurement procedure: Public Procurement Act, Public Procurement Policy (I: requiring letter, O: documentation of public procurement);

- Draft order, completing the contract: Public Procurement Act, Public Procurement Policy (I: valid proposal, O: order and/or contract);

- Completion of delivery notification: Management Regulation, Asset Management Regulation (I: record of delivery's fact, O: delivery certification).

\subsubsection{Investment and Renewal}

Processes of investment and renewal's module which were explored during the research are the following.

- Announcement of require, justification of financial cover: Management Regulation, Investment Policy (I: record of claim announcement, O: requiring letter);

- Execution of necessarily procurement procedure: Public Procurement Act, Public Procurement Policy (I: requiring letter, O: Documentation of Public Procurement);

- Draft order, completing the contract: Investment Policy, Public Procurement Regulation (I: valid proposal, O: order, contract);

- Handover of investment/renewal budget: Management Regulation (I: requiring letter, O: permission letter);

- Completion of delivery notification: Management Regulation, Asset Management Regulation, Investment Policy (I: record of delivery's fact, O: delivery certification);

- Accounting of tangible assets: Asset Management Regulation, Investment Policy, Accountancy Policy (I: delivery certification, invoice, O: Documentation of Asset Management Regulation);

- Payment of invoice: Management Regulation (I: record of verification, O: invoice, order note).

The I/O connections and nodes can be seen on the figure where the fluid transformation takes place.

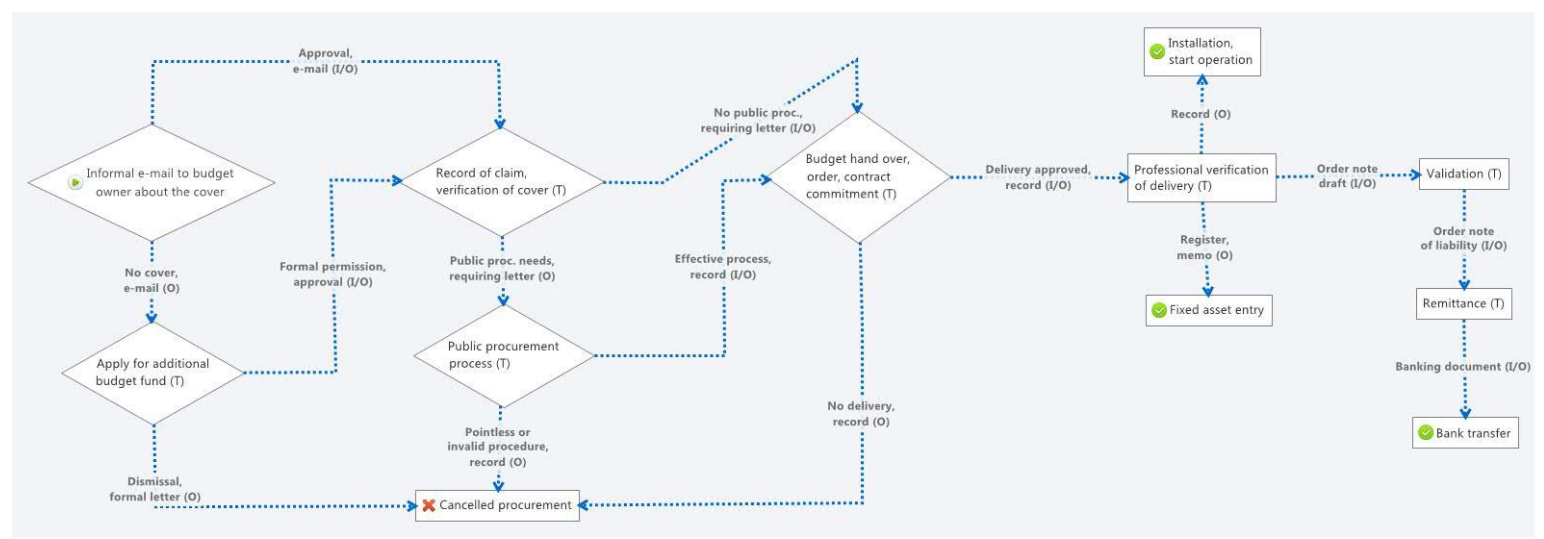

Figure 4. Process of investment and renewal (I: input, O: output, T: transformation)

Source: own editing

\subsubsection{Handover of Liquid Assets}

Revealed processes:

- Transferred financial instrument for operational purpose: Management Regulation, Public Service Regulations, agreement (I: requiring letter; O: agreement);

- Transferred financial instrument for accumulation purpose: Management Regulation, Investment Policy, agreement (I: requiring letter, O: agreement). 


\subsubsection{Public Procurements}

Processes of public procurement's module which were explored during the research are the following.

- Start of procedure: Public Procurement Act, Public Procurement Policy (I: requiring letter; O: starting letter, initiative document);

- Draft of tender documentation, compliance checking procedure: Public Procurement Act, Public Procurement Policy (I: initiative document, O: tender documentation, conflict of interest statement);

- Publication of tender documentation: Public Procurement Act, Public Procurement Policy (I: tender documentation, $\mathrm{O}$ : announcement, order note);

- Make tender documentation to available : Public Procurement Act, Public Procurement Policy (I: announcement, O: invoice, registration form from document receivers);

- Receiving proposals and opening procedure: Public Procurement Act, Public Procurement Policy (I: registration form about document receivers, O: opening record of proposal).

- Checking proposals: Public Procurement Act, Public Procurement Policy (I: opening record; O: reviewer committee record);

- Decision proposal: Public Procurement Act, Public Procurement Policy (I: reviewer committee record, O: reviewer committee record);

- Announcement of results: Public Procurement Act, Public Procurement Policy (I: reviewer committee record; O: reviewer committee record, summary about procedure's result);

- Completion of the annual aggregated public procurement: Public Procurement Act (I: requiring letter; O: public procurement plan);

- Making of preliminary aggregated handout: Public Procurement Act (I: public procurement plan, O: announcement, order note);

- Drawing up of annual statistic summary: Public Procurement Act (I: analytical register, O: statistic summary).

The I/O connections and nodes can be seen on the figure where the fluid transformation takes place.

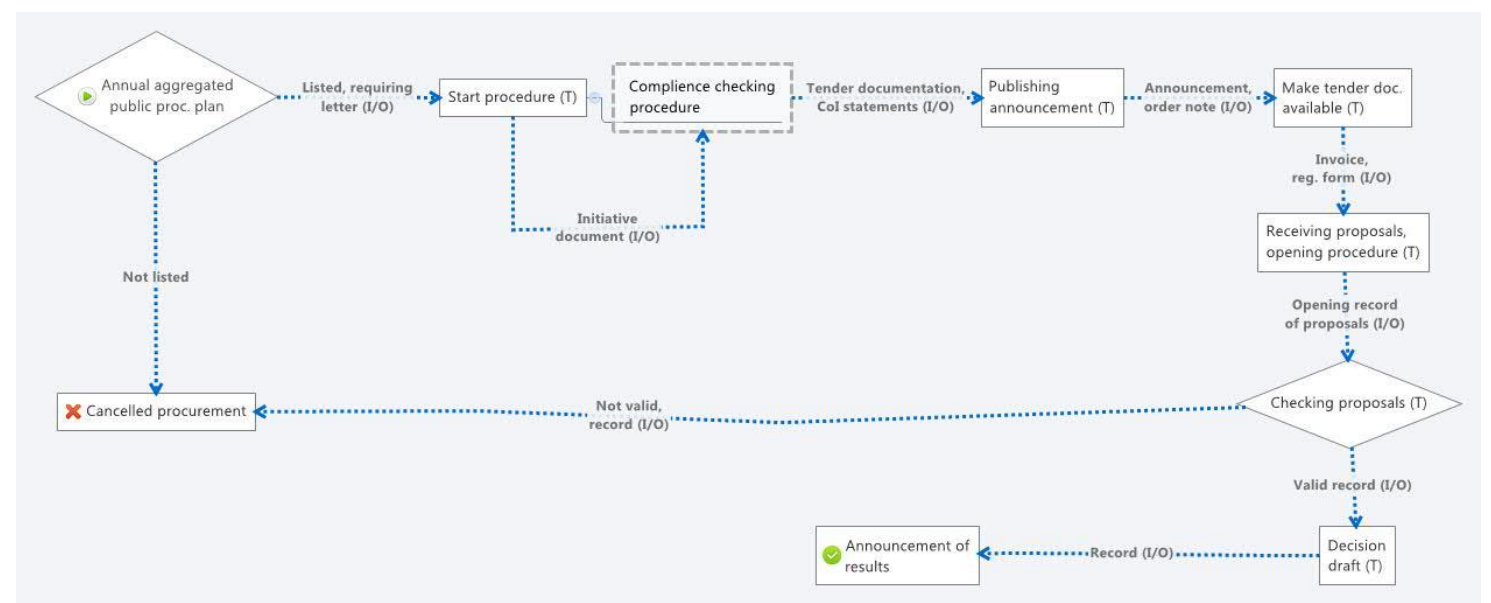

Figure 5. Process of public procurement (I: input, O: output, T: transformation)

Source: own editing

\subsubsection{Revenues}

Processes of changes in stock which were explored during the research are the following.

- Transfer of budgetary support: Public Finance Act, Execution of State Budget and Management Regulation (I: application, O: financial schedule, record from transfer);

- Operating income: Public Finance Act, Execution of State Budget and Management Regulation (I: contract, delivery verification, $\mathrm{O}$ : invoice, settlement); 
- Accumulation and capital income: Public Finance Act, Execution of State Budget and Management Regulation (I: agreement, O:certificate of invoice substitute, settlement);

- Receipt of funds: Public Finance Act, Execution of State Budget and Management Regulation (I: agreement, O: certificate of invoice substitute);

- Early financing: Public Finance Act, Execution of State Budget and Management Regulation (I: application with listed invoice statement, O: record from transfer).

\subsection{Changes in Stock}

Processes of changes in stock which were explored during the research are the following.

- Register of demands, debtors, and customers: Act on accounting, Accounting Policy, Assessment Regulation (I: certificate of invoice substitute, agreement, O: register of demand);

- Register of creditors and liabilities: Act on accounting, Accounting Policy, Assessment Regulation (I: certificate of invoice substitute, agreement, O: register of commitment);

- Monitoring of records' changes: Act on accounting, Accounting Policy (I: list of book entries, O: adjusted analytics);

- Implementation of checking: Accounting Policy, Regulations (I: checking forms, O: adjusted ledger).

\subsection{Closing Entries}

Processes of closing entries which were explored during the research are the following.

- Periodical closing entries: Act on accounting, Accounting Policy, System of accounts (I: register, checking tables, O: ledger statement);

- Preparation of cash flow report: Act on accounting, Accounting Policy, System of accounts (I: register, O: cash flow report);

- Preparation of periodical reporting boards: Accounting Policy, System of accounts (I: management instruction, O: data reporting boards).

\subsection{Budget Reporting}

Processes of budget reporting which were explored during the research are the following.

- Stocktaking: Act on accounting, Stocktaking and Asset Management Regulation (I: stocktaking circular letter, O: stocktaking lists);

- Fulfillment of checking: Accounting Policy, Regulations (I: stocktaking lists, O: checking forms, adjusted ledger);

- Creating the periodical fiscal report: Public Finance Act, Act on accounting, Execution of State Budget, Accounting Policy, Ministry for Home Affairs' guideline (I: adjusted ledger, O: periodical fiscal report and textual amendment).

\section{A Heuristic Method of the Improvement of Closed- or Public Finance Processes}

The process structure cannot be modified at public finance process. How could it be effective? Is every user in the suitable node? If perceptions and competencies of the user are not suitable in the activity then neither in modifying of the process or changing in the human resource is not a substantive opportunity.

It is appropriate to allocate the HR resources that the efficiency of the process could increase. At first sight there are two solutions:

- Swap of two users which have not suitable perception.

This solution is heuristic and make blindly. The result of this solution could damage the efficiency of the process.

- Greedy algorithm.

a) Where every process is bottleneck or we rank the perceived wrong-operated user according to their perceptions and competencies.

The process goes through by ranking of instructions in every node and put every user which has the best competencies in every node. 
The algorithm has a big fault: towards to the end of the process we could get nodes to which inappropriate and incompetent user is assigned so the process stops.

b) We combine the algorithm with swap.

This algorithm is only sketched. Later on we work-out this algorithm in detail. In the bottleneck nodes we execute paired comparisons.

We are selecting every wrong-operated node activity, swap the users in the wrong operated nodes and examine whether improved or eliminated the problem. If the problem is eliminated or improved as a consequence we remove it, but it is improved only little then we put back them with swap.

If we were not able to improve the node, then we choose from the good-operated node and carry out the same replacement process. (Remark: It could be happened that till now good-operated node get into the bad-operated nodes, but joint effect of these nodes indicate improvement.)

It appears that this method is polynomial. Additional tasks are the following:

- Ranking.

- Determination of the selection aspects and theirs sequence.

- Defining the extent of improvement - it could be the definition of the fuzzy.

- Examination of the possibility that how many times a user could swap. Swap algorithm!

- The process is converging in the direction of improvement. Sure that is available improvement, if there is.

The objective is to define a utility function before the swap in order to how useful was the swap or it damaged or improved the situation.

\subsection{Rate of Utility for Swap}

In economic processes, the material and the energy are not the primary features because the fluid is the primary, where classical physics definition of material and energy could be replaced and can be introduced entropy as the utility of swapping. Every economic process change (swap) fluid with their environment (Kasa et al., 2014).

Thus we can conclude that every organization exist from their direct environment. In case of fluid we will need the definition of entropy and it must be covered by general concept which will be also verifiable for the energy, material and information, etc. That is why we need a concept in case of information which has equivalent in the energy systems:

- Bound information - data, which has no semantic content or no new knowledge.

- Free information - a data, which means new knowledge for the system.

In the process of information processing, if we close the economic system from the external effect and allow their flow in the system, then in every point of the process the economic process become data. If suitable data will be everywhere the equilibrium is reached, and it is not turning by itself back, namely there will not be information in the system again (Schulte et al., 2014).

It is important to note, that the economic process (in our case this is system process) is an opened system, and form a closed system with only their environment. That is the flowing fluid from their environment could complicate their system and increase the non-transparency and disordering. This means that the incoming cases, files and information in the system could greatly increase the disordering of the system. Striving for a new organization or orderliness of organizational structure, perhaps a new organizational unit or a new process is able to increase the entropy of the system.

\subsection{The Entropy}

- It is also true, that every economic process exist from the fluids in their direct environment, like in the case of physical system from the free energy.

- Examine, how the entropy could be defined the in case of a process system.

It is important, that we are able to assign an energy quantity to the fluid. Let "d" be a fluid. In order to define energy for it, the following aspects should be considered:

- Characterize the current state of the fluid, so this is time factor.

- The energy of the flowing fluid could be given by that information or energy quantity which a fluid flow system could be changed from initial condition to another condition. 
- The free energy of the fluid means the quantity of the free information or energy, namely those data, which has new knowledge.

- The bound energy of the fluid means the quantity of the bound information or energy, that is those data which has no semantic content or not constitute new knowledge.

- Information quantity of the fluid refers to the probability which the system provide theirs duties in the fluid-flow system. (This value can be approached by statistical analyses of the system.)

The entropy can be given by the following characteristics:

- The entropy must be measurable feature.

- The free energy fluid must be low value; in case of the bound energy fluid must be high value.

- In case of closed-system process system from the free energy fluids will continuously become bound energy fluid, so the internal entropy should be increased as much as energy transformed.

- From the bound energy fluid could only be re-established to free energy fluid by sensing and processing of new external fluid.

- If the growth of the fluid is fast and the fluid energy of the system is in balance quickly.

- "S function" could be assigned to each equilibrium system, entropy of the system, which is the function of the extensive parameters describing the status of the system.

It is also evident that in case of information Shannon entropy

$$
S=\log 1 / p
$$

definition will be used. As information has the smaller probability (excluding the impossible event) the bigger free energy it has. That could create energy changing in a fluid-flow, so meets the above requirements. In case of bound energy fluid, if it means information then it does not give new knowledge, so theirs probability 1 or 0 , therefore their entropy is 0 . All these served that the utility of swap could be measured by fluids of entropy used during the swapping.

Finally, after these, the entropy can be drafted namely the entropy of the fluid is the energy which established for fluid flowing in the fluid-flow.

\section{Summary}

In this article we introduced three aspect of our research. In the first part, we analyzed the process of an independent Hungarian public finance institute. Primarily we analyzed where and what ways we have opportunity to repair the processes. In fact these are much bounded processes, so we could only achieve results by changing the node's activity. Hereinafter our analyses were focused to intern-users in the nodes. Due to the hard process structure it is possible to swap the users in the way that give up user (not the method of lean) and we will be able to use the users more efficiency as resources. We realize the above mentioned tasks with heuristic swap, later on the elaboration of the swap will be work-out in detail.

Since the swap requires a sort of utility approach. In order to the defining of the utility we introduced the entropy which is generated by fluids in the fluid-flow. It could be appear that utility is a signed value while the fluid entropy could be never negative. Thus creating the utility in rate of entropy (always align to the situation), we highlight a virtual zero point, and if the value is below this virtual zero point the utility will be negative. On the other hand if the value is higher the utility will be positive. So the common goal of the seemingly three different part of the article is improving the public finance processes.

\section{Conclusions}

The steps of the economic processes of public finance organizations, the appearing phases and the explored processes constitute a unified system. In many cases the operation of the system is not suitable, because the processes do not reflect the flow of information, documents, etc. flowing in the process. We started the researches with the explored processes' general attributes identification, then for this we built the definitions and attributes of the object-flows.

According to the explored processes and fluids the perceptional analysis of the nodal human resources can be established - can be established a perception-scale too- as a consequence the process improvement can be carried out. Another option for the process improvement could be the change of transformation in the node. By the modifying of the perceptional sensitive human resource and the not enough effectively transformation the public sector economic processes can be improved (within the legal limits) and minimize the error rate. 
According to the study's purpose we examined the steps of the budgetary management, the processes and the identification of the related fluids, their flows and transformations too. This is the first phase of the multi-step process as consequence we form a methodology for the system-level examination of the budgetary management processes. From this methodology a customized method can be create for the further tested public sector institution.

\section{References}

Guban, A., \& Kasa, R. (2013). A Literature Based Review of Business Process Amelioration Methods and Techniques Regarding Service Orientation. Journal of Advanced Management Science, 1(2), 230-235. https://doi.org/10.12720/joams.1.2.230-235

Kasa, R. et al. (2014). The concept of perception driven service process reengineering by entropy reduction. Pannon Management Review, 3(1), 11-54

Kasa, R., \& Guban, A. (2014). Rethinking Production Processes Based on Fluid Flow Analysis. In Eighteenth International Working Seminar on Production Economics. Congress location: Innsbruck.

Mezei, Z., \& Guban, A. (2014). Economic processes in public sector. Advanced Logistic Systems, 8(2), 51-62.

Palne, K. I. (2008). Helyi kormányzás Magyarországon. Dialog Campus Kiadó, Budapest.

Pollit, C., van Thiel, S., \& Homburg, V. (Eds.) (2007). New public management in Europe: Adaption and alternatives. Palgrave Macmillan, Hampshire. https://doi.org/10.1057/9780230625365

Schulte, S. et al. (2014). Elastic Business Process Management: State of the art and open challenges for BPM in the cloud. Information Systems, 48(1), 26-43.

Sivak, J., \& Vigvari, A. (2012). Rendhagyó bevezetés a közpénzügyek tanulmányozásába. CompLex Kiadó, Budapest.

Stojkic, Z., Visekruna, V., \& Majstorovic, V. (2013). Application of Organizational Tools and Software Solutions in Order to Increase the Efficiency of Business Processes. In B. Katalinic \& Z. Tekic (Eds.), Chapter 07 in DAAAM International Scientific Book 2013 (pp. 173-192). Published by DAAAM International, Vienna. https://doi.org/10.2507/daaam.scibook.2013.07

\section{Internal documentation}

Hungarian Prison Service's memorandum of association

Hungarian Prison Service's organizational and operational regulation

Hungarian Prison Service's controlling pathway

\section{Copyrights}

Copyright for this article is retained by the author(s), with first publication rights granted to the journal.

This is an open-access article distributed under the terms and conditions of the Creative Commons Attribution license (http://creativecommons.org/licenses/by/4.0/). 